\title{
Study of three days duration coupling between jets in South América
}

It can be understood by coupling between jets when Upper-Level Jet (UL) superimposes the Low-Level Jet (L $U$ ). The literature shows that such couplings tend to generate or intensify surface instabilities. Thus, the objective of this study was to analyze the synoptic configuration and the coupling between the jets associated with storms during the period of October 28-30, 2019, when instabilities hit southern Brazil causing intense precipitation and several damages. This work was carried out through the analysis of meteorological fields employing ERA5 reanalysis data and GOES-16 satellite imagery. The coupling between jets was verified in the three days of study. Upward vertical movements at $500 \mathrm{hPa}$ was observed in the same area of occurrence of the upper level difluent flow, as well as an intense $850 \mathrm{hPa}$ northerly flow, a large amount of moisture due to the action of the Northwestern Argentinean Low, and the presence of a frontal system between Uruguay and RS, except on the first day. Storms developed east (downstream) of the area where the coupling took place. The coupling was observed before and during the development of the mesoscale convective systems, and its dissipation occurred simultaneously with the storm. However, on the 30th, the peak of coupling did not occur together with the most intense phase of the system, it occurred before.

Keywords: Severe Weather; Low Level Jet; Jet Stream.

\section{Estudo de acoplamento entre jatos com duração de três dias na América do Sul}

\begin{abstract}
Entende-se por acoplamento entre jatos quando o Jato de Altos Níveis (JAN) se sobrepõe ao Jato de Baixos Níveis (JBN). A literatura mostra que tais acoplamentos tendem a gerar ou intensificar instabilidades em superfície. Desta forma, o objetivo desse estudo foi analisar a configuração sinótica e o acoplamento entre os jatos associados a tempestades durante o período de 28 a 30 de outubro de 2019, quando ocorreram instabilidades que atingiram o sul do Brasil, causando precipitação intensa e diversos estragos. O trabalho realizou-se por meio da análise de campos meteorológicos usando dados de reanálise do modelo ERA5 e imagens do satélite GOES-16. Foi verificado acoplamento entre os jatos nos três dias de estudo. Foram observados movimentos verticais ascendentes em $500 \mathrm{hPa}$ na mesma área de ocorrência do escoamento difluente em altos níveis, bem como um intenso escoamento de norte em $850 \mathrm{hPa}$, um grande aporte de umidade proveniente da atuação da Baixa do Noroeste Argentino, e a presença de um sistema frontal entre o Uruguai e o RS, exceto no primeiro dia. A leste (corrente abaixo) da área onde ocorreu o acoplamento houve desenvolvimento de tempestades. O acoplamento foi observado antes e durante o período de atuação dos sistemas convectivos de mesoescala, e a dissipação desse ocorreu simultaneamente com a tempestade. Contudo no dia 30, o pico de acoplamento não ocorreu junto a fase mais intensa do sistema, ocorreu antes.
\end{abstract}

Palavras-chave: Tempo Severo; Jato de Baixos Níveis; Corrente de jato.

Topic: Meteorologia, Climatologia e Mudanças Climáticas

Reviewed anonymously in the process of blind peer
Received: 03/02/2021

Approved: $26 / 02 / 2021$
Emily Claudia Pereira Ramos

Universidade Federal de Pelotas, Brasil

http://lattes.cnpq.br/5865759140378282

http://orcid.org/0000-0001-5467-0817

emillycpramos@gmail.com

Luiz Gabriel Cassol Machado (iD)

Universidade Federal de Pelotas, Brasil

http://lattes.cnpq.br/3974372778849875

http://orcid.org/0000-0003-1561-0701

gabrielcassol09@gmail.com

André Becker Nunes (iD

Universidade Federal de Pelotas, Brasil

http://lattes.cnpq.br/1873505066686878

http://orcid.org/0000-0002-4881-5810

beckernunes@gmail.com
Referencing this:

RAMOS, E. C. P.; MACHADO, L. G. C.; NUNES, A. B.. Study of three days duration coupling between jets in South América. Revista Ibero Americana de Ciências Ambientais, v.12, n.2, p.240-248, 2021. DOI: http://doi.org/10.6008/CBPC2179-6858.2021.002.0023 


\section{INTRODUCTION}

Located in a subtropical climate zone, the Central-South region of South America (SA) is characterized by variability of meteorological systems that occur throughout the year, such as cold surges, squall lines, mesoscale convective systems (MCS), among others (GRIMM, 2009; REBOITA et al., 2012). This region presents well-defined seasons with little rainfall variation, the west of the southern Brazil is the location with the highest rainfall rates, ranging from 1050 to $1750 \mathrm{~mm}$ annually (REBOITA et al., 2010).

In some regions of the globe, intense synoptic meridional flows are observed in the lower troposphere, around 1500 meters high. When such flow meet the criteria suggested by Bonner (1968) it is called Low Level Jet (LL). According to Paegle (1998) an LL appears east of an elevated topography, in SA it occurs east of Andes, presenting acceleration towards south (MARENGO et al., 2004). The SA-LLJ occurs throughout the year, however, it is an element of the monsoon system, transporting warm and moist air from the Amazon basin to the Paraná-Prata basin, favoring convective activity at the jet exit (MARENGO et al., 2002; NASCIMENTO, 2005). Salio et al. (2007) showed that during the warm seasons SA-LL contributes to the development of MCSs, mainly in northern Argentina, Paraguay and west of southern Brazil.

MCSs are cloud clusters, most of them convective with very cold tops, that is, with great vertical development. These systems are responsible for much of the rainfall occurring in the tropics and in many mid latitudes regions (HOUZE JUNIOR, 1993). The MCS convective cells can negatively impact society by causing floods, strong winds, thunderstorms and hail (WALLACE et al., 2006).

Synoptically, South American mid latitudes MCSs are generated by two continental low-pressure surface systems, Chaco Low (CL) and Northwestern Argentinean Low (NAL). CL is most easily observed at warm season, being generated by the release of latent heat due to the convection that occurs over the Chaco Plain, and generally develops to the north of the subtropical jet. The SA-LL's characteristic of transporting heat and humidity toward high latitudes tends to deepen CL and NAL (SALIO et al., 2002; SELUCHI et al., 2012). Unlike the origin of $C L, N A L$ is usually located closer to the Andes, being influenced by transient systems and orography (ESCOBAR et al., 2012).

At mid latitudes, near the tropopause, an almost horizontal narrow band of intense wind is observed, called the Upper Level Jet (ULJ), or simply jet stream. This phenomenon is often related to events of intense convection, since it is directly associated with baroclinic systems such as extratropical cyclones and frontal systems (ESCOBAR, 2009; FEDOROVA et al., 2017). Diffluence conditions in the flow of UL lead to an increase in air evacuation, mass divergence at upper levels and convergence at lower levels, which tends to intensify surface instabilities (BLUESTEIN, 1993; SANDERS, 1993).

Cassol Machado et al. (2019) observed a diffluent flow at upper levels associated with a case of intense precipitation in Rio Grande do Sul State (RS), in which some cities recorded values above $100 \mathrm{~mm}$ in a few hours. Lara et al. (2019), in a study on tornado cases in RS, also observed upper-level difluence associated with an event in Tapejara-RS, and in Canela-RS a coupling between jets was verified.

Uccelini et al. (1979) observed convective instabilities developing under situations of coupling 
between the jets, and that the orthogonality of the axes would result in greater conditions for the formation of storms due to cold advection from the jet stream superimposed on the heat transport from LL (NASCIMENTO, 2005). Through numerical simulations of a storm case, Brill et al. (1985) identified a transverse circulation at the jet stream exit due to the ageostrophic wind. Such circulation was directly associated with the LLJ. A similar behavior was observed by Sortais et al. (1993). The overlapping of the jet axes suggests an intense vertical wind shear, resulting in a strong convective instability crucial to the formation of MCS.

Thus, the objective of this work is to analyze the synoptic environment, with coupling between jets, related to the storms that hit southern Brazil causing several damages between October 28 and 30, 2019. The knowledge of this phenomena is an important additional tool to understand the behavior of convective systems in southeastern SA.

\section{METHODOLOGY}

The case was analyzed using reanalysis dataset from ERA5, the fifth generation of reanalysis from the European Center for Medium-Range Weather Forecasts (ECMWF) ${ }^{1}$ (HERSBACH et al., 2019). ECMWF reanalysis data is widely used in meteorological studies. For example, according to Montini et al. (2019) the ERA-Interim reanalysis, a version prior to ERA5, showed the best results in LLJ estimate compared to other reanalyzes. The ERA5 data provides hourly variables on a $0.25^{\circ}$ spatial resolution and 137 vertical levels.

Convective instabilities were identified in the thermal infrared channel imagery from GOES-16 (Geostationary Operational Environmental Satellite 16), obtained from the DSA/INPE (Division of Satellites and Environmental Systems/National Institute for Space Research) website ${ }^{2}$. Accumulated precipitation data was obtained from the INMET (National Institute of Meteorology) meteorological stations network, via web³.

The LLJ was identified according to basic criteria from Bonner (1968), adapted by Salio et al. (2002), that is, the $850 \mathrm{hPa}$ wind must exceed $12 \mathrm{~m} \mathrm{~s}^{-1}$ and the meridional (southward) component must be greater (in modulus) than the zonal. However, the vertical wind shear criterion (6 $\mathrm{m} \mathrm{s}^{-1}$ between 850 and $700 \mathrm{hPa}$ ) was not considered, so that cases like the one presented in Oliveira et al. (2018) are not discarded. ULJ was identified when the mid latitudes $250 \mathrm{hPa}$ wind is greater than or equal to $30 \mathrm{~m} \mathrm{~s}^{-1}$ (REITER et al., 2005).

The coupling field was obtained from the difference in degrees of the directions of the jets, calculated at the grid points where the UJL overlaps the LLJ, that is, when the coupling occurs. The difference in degrees between them is subtracted $90^{\circ}$, therefore the smaller the value of the coupling field, the more orthogonal (more intense).

\section{RESULTS AND DISCUSSION}

\section{On 28 October 2019}

\footnotetext{
${ }^{1}$ https://cds.climate.copernicus.eu/\#!/search?text=ERA5\&type=dataset

2 http://satelite.cptec.inpe.br/acervo/goes16.formulario.logic

3 https://tempo.inmet.gov.br/PrecAcumulada
} 
In the mean sea level pressure field at 09 UTC 28 October 2019 (Figure 1A) the NAL is observed over northern Argentina, extending an inverted trough over RS and Uruguay, contributing to the intensification of the LL, as indicated by Seluchi et al. (2012).
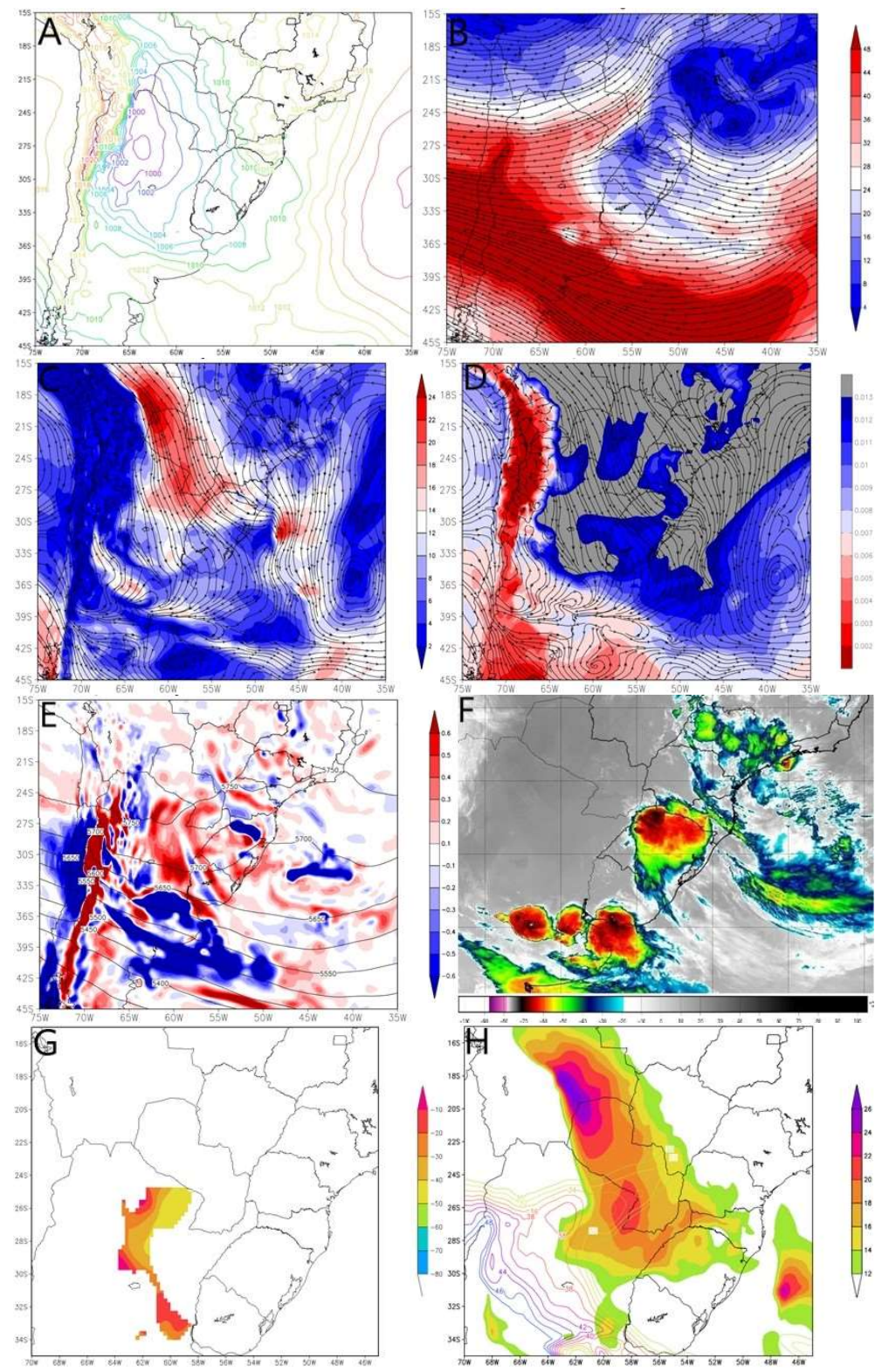

Figura 1: Fields for 10/28/2019 at 09 UTC. A) Mean Sea Level Pressure (hPa). B) $250 \mathrm{hPa}$ streamlines (contour) and wind strength (shaded) $\left(\mathrm{m} \mathrm{s}^{-1}\right)$. C) $850 \mathrm{hPa}$ streamlines (contour) and wind strength (shaded) $\left(\mathrm{m} \mathrm{s}^{-1}\right)$. D) $850 \mathrm{hPa}$ streamlines (contour) and specific humidity (shaded) $\left(\mathrm{g} \mathrm{kg}^{-1}\right)$. E) $500 \mathrm{hPa}$ geopotential height (contour) (mgp) and omega vertical velocity (shaded) (Pa s${ }^{-1}$ ). F) GOES-16 infrared image. G) Coupling between jets (degrees). H) LLJ (shaded) and UL (contour) strength (m s-1).

A $250 \mathrm{hPa}$ diffluent flow over the north of RS and west of SC was observed, from the moment of formation of MCS (not shown) until the moment of greater intensity of the system (Figure 1F).

Figure $1 \mathrm{C}$ shows an intense core (more than $20 \mathrm{~m} \mathrm{~s}^{-1}$ ) of $850 \mathrm{hPa}$ northerly wind over northern Paraguay, extending less sharply to the west and north of RS, indicating the occurrence of LLJ. This northern flow represents the transport of warm and humid air from the Amazon basin, providing support for the formation of storms. With part of this north flow converging on the north and west of RS, a large amount of humidity at low levels is observed over the region (Figure 1D), favoring the origin of surface instabilities. 
Several works, such as Teixeira et al. (2007), Riquetti et al. (2018), Caballero et al. (2018) and Dorneles et al. (2020), indicate the association between LLJ-NAL (or LLJ-CL in the summer) with events of intense precipitation in the southern Brazil.

A small amplitude ridge extending onto RS (Figure 1E) is observed in $500 \mathrm{hPa}$, along with high thickness values (around $5750 \mathrm{mgp}$, not shown here), indicating a more unstable atmospheric layer due to warm air. The omega field (Figure 1E) shows localized intense upward vertical movement over the region at the same moment of greatest SCM intensity (Figure 1F).

The strength of the jets (Figure $1 \mathrm{H}$ ) indicate great vertical shear (mainly within the coupling) before (not shown), during (Figure 1G) and after (not shown) system occurrence, presenting values closer to orthogonality ( 0 ㅇ) during the most active phase of the MCS (Figure 1F), although the MCS was located downstream (east of) the coupling. According to 24-hour accumulated precipitation data maps from INMET, the northern half of RS showed several points above $50 \mathrm{~mm}$ on October 28, 2019, mainly in the west, with points above $80 \mathrm{~mm}$.

\section{On 29 October 2019}

The following day, the inverted trough over the RS associated with NAL can still be seen. However, on the border with Uruguay there is a frontal system from an extratropical cyclone in Atlantic. The southern flow (Figure 2C) from the cold branch of frontal system and the northern flow from warm branch contributed to the instability growth. The difluence of upper levels flow persisted throughout the morning of the 29th. At low levels the continuous presence of $\mathrm{LJ}$ is perceived, transporting warm and moist air to RS (Figure 2C), collaborating with the high specific humidity at $850 \mathrm{hPa}$ over the entire border of RS with Uruguay and Argentina (Figure 2D).

There is a ridge at $500 \mathrm{hPa}$ over southern Brazil associated with low levels warm air flow, indicating an unstable atmosphere, where intense upward movements (Figure 2E) led to the boost of the difluence already established at $250 \mathrm{hPa}$ (Figure 2B). The enhancement of surface instabilities configured an SCM with greater intensity than the previous day (Figure 2F). These mesoscale systems caused significant precipitation in the southern half of RS, with values above $30 \mathrm{~mm}$ according to INMET precipitation maps.

There were small coupling cores between 03 and 12 UTC, since at 03 UTC there was the formation of a first MCS, intense, but which reached an area smaller than the second one. However, here the 09 UTC image is shown because it is the moment with the greatest coupling (Figure $2 \mathrm{G}$ ) and the greatest system intensity (Figure 2F).

As in the previous day, the coupling occurred between the exit of LLJ and the tropical sector of UL, and upstream the MCS (Figures $2 \mathrm{~F}-\mathrm{H}$ ). The high strength of the jets indicate a strong vertical wind shear, which implies intense convective activity, an important factor for the formation of the two convective systems (not shown) observed on the 29th. 

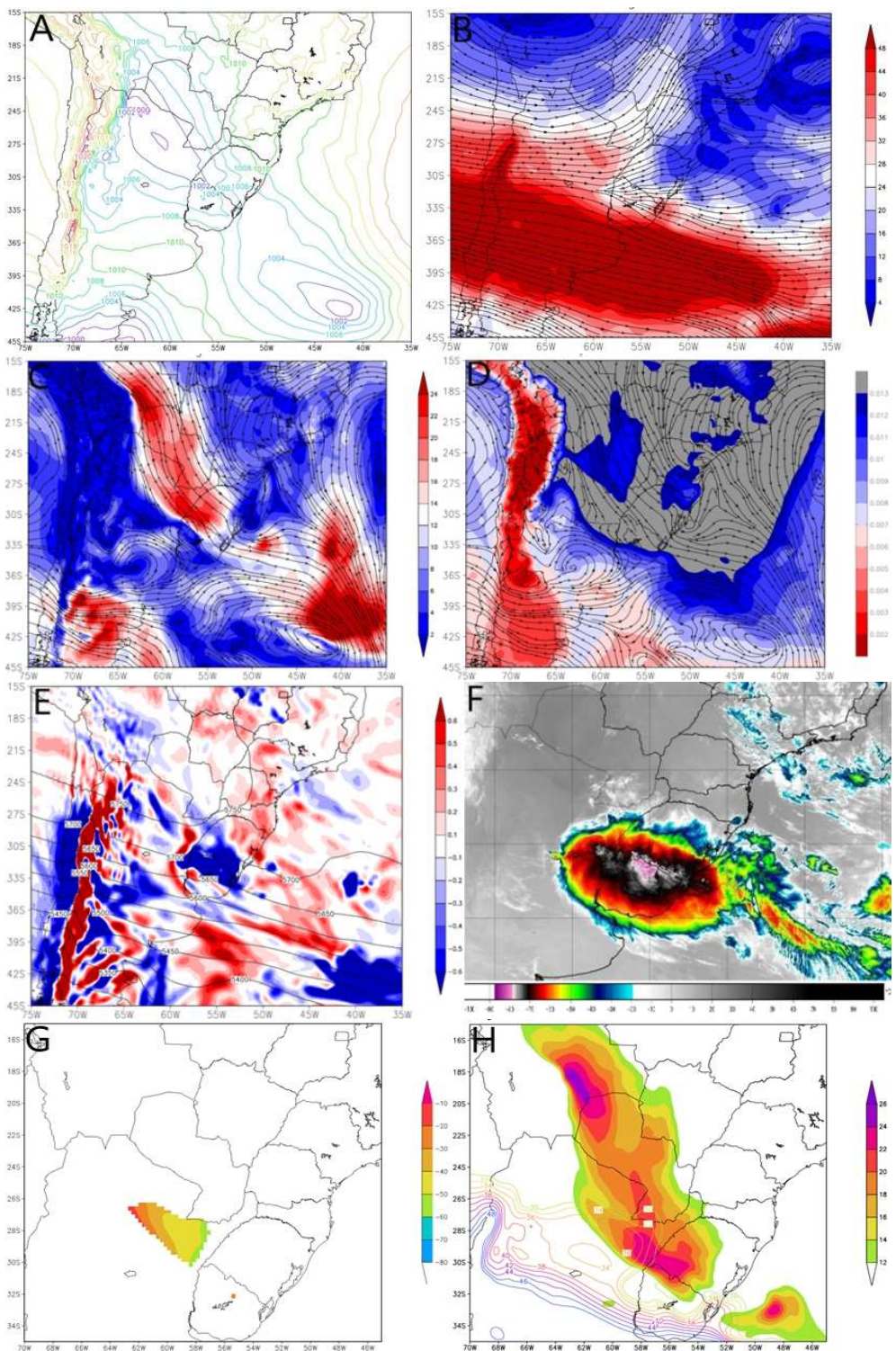

Figura 2: Fields for 10/29/2019 at 09 UTC. A) Mean Sea Level Pressure (hPa). B) $250 \mathrm{hPa}$ streamlines (contour) and wind strength (shaded) $\left(\mathrm{m} \mathrm{s}^{-1}\right)$. C) $850 \mathrm{hPa}$ streamlines (contour) and wind strength (shaded) $\left(\mathrm{m} \mathrm{s}^{-1}\right)$. D) $850 \mathrm{hPa}$ streamlines (contour) and specific humidity (shaded) $\left(\mathrm{g} \mathrm{kg}^{-1}\right)$. E) $500 \mathrm{hPa}$ geopotential height (contour) (mgp) and omega vertical velocity (shaded) (Pa s-1 $)$. F) GOES-16 infrared image. G) Coupling between jets (degrees). H) LLJ (shaded) and UL (contour) strength (m s-1).

\section{On 30 October 2019}

On October 30 the synoptic environment remains with little change, with the inverted trough associated with NAL over RS and the cold front moving away from the continent (Figure 3A).

On this third day of analysis, upper-level difluence was observed until the morning (Figure 3B), intensifying at the exact moment of greatest surface instability (Figure 3F). At low levels, the LL continues to influence the high values of specific humidity in the region (Figures $3 C-D$ ).

Such difluence is a consequence of intense upward movements, which in turn are associated with a warm layer, as indicated by the persistent ridge at $500 \mathrm{hPa}$ (Figure 3E). Figure 3F shows the formation of a new MCS, elongated type, similar to the one on the 29th, which lasted for several hours in southern Brazil. This system caused heavy rain in the southern half of RS, with values above $50 \mathrm{~mm}$, especially in the Campanha region $(80 \mathrm{~mm})$. 


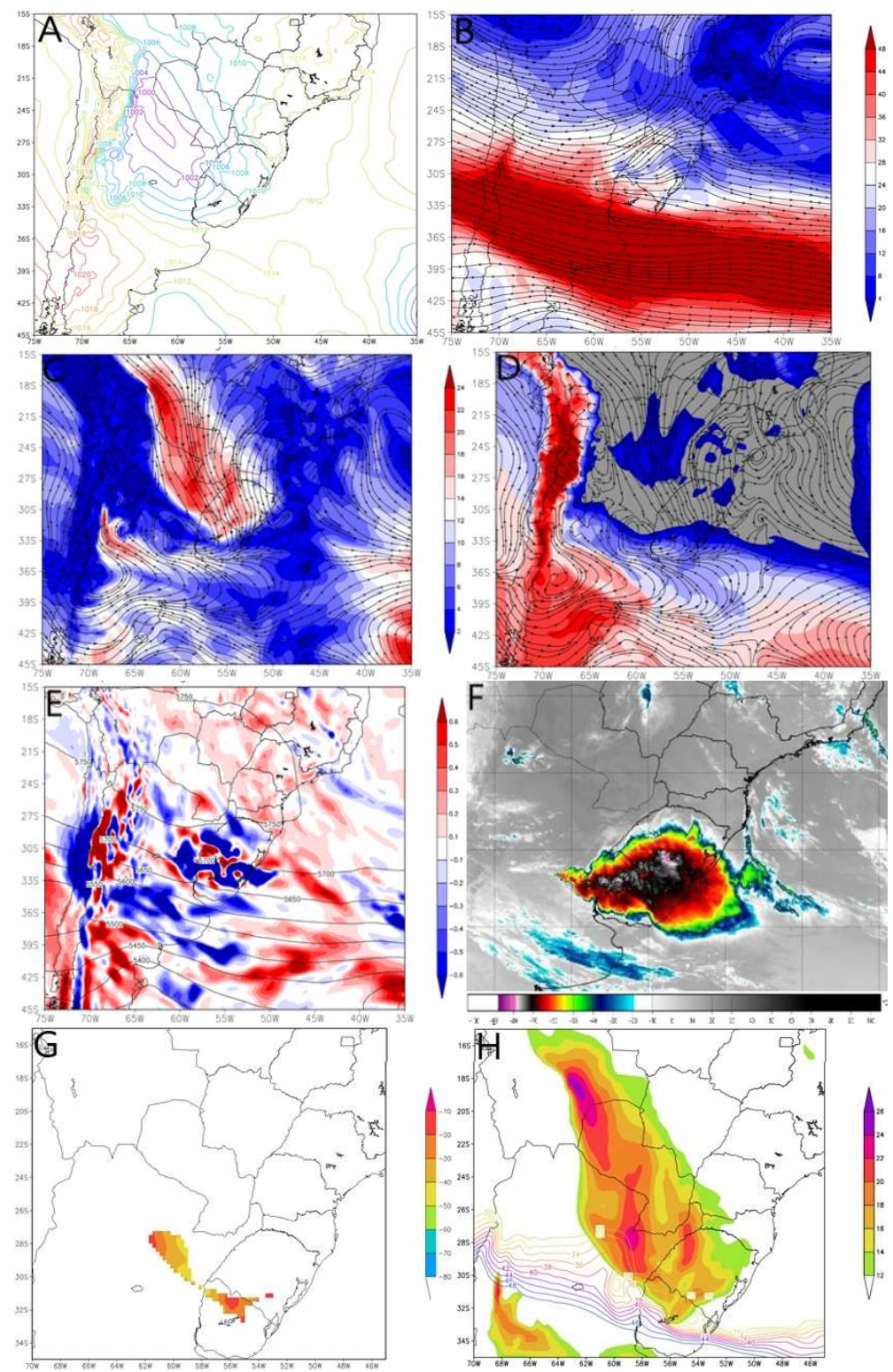

Figura 3: Fields for 10/30/2019 at 09 UTC. A) Mean Sea Level Pressure (hPa). B) $250 \mathrm{hPa}$ streamlines (contour) and wind strength (shaded) $\left(\mathrm{m} \mathrm{s}^{-1}\right)$. C) $850 \mathrm{hPa}$ streamlines (contour) and wind strength (shaded) (m s${ }^{-1}$ ). D) $850 \mathrm{hPa}$ streamlines (contour) and specific humidity (shaded) $\left(\mathrm{g} \mathrm{kg}^{-1}\right)$. E) $500 \mathrm{hPa}$ geopotential height (contour) (mgp) and omega vertical velocity (shaded) ( (a s $^{-1}$ ). F) GOES-16 infrared image. G) Coupling between jets (degrees). H) LLJ (shaded) and ULJ (contour) strength ( $\mathrm{m} \mathrm{s}-1)$.

There were intense cores of jet coupling before (not shown) and during (figure 3G) the storm. The most intense coupling time occurred at 062 (not shown), that is, the coupling closest to the orthogonal occurred before the instabilities, but here the 09 UTC fields are shown (figure 3G-H), when the cloudiness was more intense (figure 3F). As in previous days, the convective system occurred downstream the coupling. In the dissipation stage of the system, not shown here, there was also no coupling.

\section{CONCLUSIONS}

A coupling between LLJ and ULJ was identified in South America on October 28, 29 and 30, 2019. The development of storms, which caused intense precipitation and several damages in southern Brazil, was observed downstream the coupling. The coupling was observed before and during the life span of the MCSs, and its dissipation occurred along with that of the storm. It should be noted that on the 30th the most intense 
coupling (close to the orthogonal) did not occur simultaneously with the most intense phase of the system, it occurred before. It is understood here, according to previous studies, that coupling must have contributed to the development of the convective instabilities observed in this work.

In the three days under analysis, in addition to the coupling, a synoptic environment composed by the ULJ was observed, which intensified the trough associated with NAL and carried heat and humidity from the north, heating the layer as indicated by geopotential height field. The warm and moist atmospheric layer supported upward movements and diffluent flow at upper levels over RS. Except on the first day studied, a frontal system was observed between Uruguay and RS.

Future work will be carried out in order to check whether in most cases the coupling occurs before and during the lifetime of the storms. In addition, the relationship between coupling and transverse indirect circulation of the ageostrophic wind should be studied.

\section{REFERENCES}

BLUESTEIN, H. B.. Synoptic-Dynamic Meteorology in Midlatitudes. Volume II: Observations and Theory of Weather Systems. Oxford: Oxford University Press, 1993.

BONNER, W. D.. Climatology of the low level jet. Monthly Weather Review, v.96, n.12, p.833-850, 1968.

BRILL, K. F.; UCCELLINI, L. W.; BURKHART, R. P.; WARNER, T. T.; ANTHES, R. A.. Numerical simulations of a transverse indirect circulation and low-level jet in the exit region of an upper-level jet. Journal of the Atmospheric Sciences, v.42, n.12, p.1306-1320, 1985. DOI:

https://doi.org/10.1175/1520-

0469(1985)042<1306:NSOATI>2.0.CO;2

CABALLERO, C. B.; OGASSAWARA, J. F.; DORNELES, V. R.; NUNES, A. B.. A precipitação pluviométrica em Pelotas/RS: tendência, sistemas sinóticos associados e influência da ODP. Revista Brasileira de Geografia Física, v.11, n.04, p.1429-1441, 2018. DOI: https://doi.org/10.26848/rbgf.v11.4.p1429-1441

MACHADO, L. G. C.; NUNES, A. B.; RAMOS, E. C. P.. Análise do campo de difluência em altos níveis em dois casos de precipitação intensa no sul do Brasil. In: SIMPÓSIO INTERNACIONAL DE CLIMATOLOGIA, 8. Anais. Belém, 2019. p.790-801.

DORNELES, V. R.; RIQUETTI, N. B.; NUNES, A. B.. Forçantes dinâmicas e térmicas associadas a um caso de precipitação intensa sobre o Rio Grande do Sul, Brasil. Revista Brasileira de Climatologia, v.26, n.16, p.220-232, 2020. DOI: http://dx.doi.org/10.5380/abclima.v26i0.58162

ESCOBAR, G.. Jato de Altos Níveis. In: CAVALCANTI, I. F. A.; FERREIRA, N. J.; SILVA, M. G. A. J.; DIAS, M. A. F. S. S.. Tempo e Clima no Brasil. São Paulo: Oficina de Texto, p.127-134, 2009.

ESCOBAR, G. C. J.; SELUCHI, M. E.. Classificação sinótica dos campos de pressão atmosférica na América do Sul e sua relação com as baixas do Chaco e do Noroeste argentino. Revista Brasileira de Meteorologia, v.27, p.365-375, 2012. DOI: https://doi.org/10.1590/S0102-77862012000300011
FEDOROVA, N.; LYRA, M. J. A.. Corrente de Jato e Fenômenos Associados. In: MARIANO, G. L.; NUNES, A. B.. Meteorologia em Tópicos: Volume 5. Pelotas: Clube dos Autores, 2017. p.11-68.

GRIMM, A. M.. Clima da Região Sul do Brasil. In: CAVALCANTI, I. F. A.; FERREIRA, N. J.; SILVA, M. G. A. J.; DIAS, M. A. F. S.. Tempo e Clima no Brasil. São Paulo: Oficina de textos, 2009. p.259-275.

HERSBACH, H.; BELL, B.; BERRISFORD, P.; HORÁNYI, A.; SABATER, J. M.; NICOLAS, J.; RADU, R.; SCHEPERS, D.; SIMMONS, A.; SOCl, C.; DEE, D.. Global reanalysis: goodbye ERA-Interim, hello ERA5. ECMWF Newsletter, Spring, n.159, p.17-24, 2019. DOI: https://doi.org/10.21957/vf291hehd7

HOUZE JUNIOR, R. A.. Mesoscale convective systems. Cloud Dynamics. San Diego: Academic Press, 1993.

LARA, K. S.; NUNES, A. B.; GOMES, R. G.; CALVETTI, L.. Condições atmosféricas de grande escala associadas a três eventos de tornados ocorridos no Estado do Rio Grande do Sul, Brasil. Revista Brasileira de Geografia Física, v.12, n.4, p.1310-1326, 2019. DOI:

https://doi.org/10.26848/rbgf.v12.4.p1310-1326

MARENGO, J. A.; SOARES, W. R.. Episódios de jatos em baixos níveis ao leste dos Andes durante 13-19 de abril de 1999. Revista Brasileira de Meteorologia, v.17, n.1 p.35-52, 2002.

MARENGO, J. A.; SOARES, W. R.; SAULO, C.; NICOLINI, M.. Climatology of the low level jet east of the Andes as derived from the NCEP-NCAR reanalysis: Characteristics and temporal variability. Journal of Climate, v.17, n.12, p.22612280, 2004. DOI: https://doi.org/10.1175/15200442(2004)017<2261:COTLJE>2.0.CO;2

MONTINI, T. L.; JONES, C.; CARVALHO, L. M. V.. The South American Low-Level Jet: A New Climatology, Variability, and Changes. Journal of Geophysical Research: Atmospheres, v.124, n.3, p.1200-1218, 2019. DOI: https://doi.org/10.1029/2018JD029634 
NASCIMENTO, E. L.. Previsão de tempestades severas utilizando-se parâmetros convectivos e modelos de mesoescala: uma estratégia operacional adotável no Brasil. Revista Brasileira de Meteorologia, v.20, n.1, p.121140, 2005.

OLIVEIRA, M. I.; NASCIMENTO, E. L.; KANNENBERG, C.. A new look at the identification of low-level jets in South America. Monthly Weather Review, v.146, n.7, p.2315-2334, 2018. DOI: https://doi.org/10.1175/MWR-D-17-0237.1

PAEGLE, J.. A comparative review of South American low level jets. Meteorologica, v.23, p.73-81, 1998.

REBOITA, M. S.; GAN, M. A.; ROCHA, R. P.; AMBRIZZI, T.. Regimes de precipitação na América do Sul: uma revisão bibliográfica. Revista Brasileira de Meteorologia, v.25, n.2, p.185-204, 2010.

REBOITA, M.; KRUSCHE, N.; AMBRIZZI, T.; ROCHA, R.. Entendendo o tempo e o clima na América do Sul. Terra e Didática, Campinas, v.8, p.34-50, 2012.

REITER, E.; BIERLY, G.. Jet Streams. In: OLIVER, J. E.. Encyclopedia of World Climatology. Dordrecht: Springer, p.435-439, 2005.

RIQUETTI, N. B.; DORNELES, V. R.; NUNES, A. B.. Estudo do caso de precipitação intensa sobre Foz do Iguaçu-PR em setembro de 2015. Revista Brasileira de Climatologia, v.22, p.589-606, 2018. DOI:

http://dx.doi.org/10.5380/abclima.v22i0.58304

SALIO, P.; NICOLINI, M.; ZIPSER, E. J.. Mesoscale convective systems over southeastern South America and their relationship with the South American low-level jet. Monthly Weather Review, v.135, n.4, p.1290-1309, 2007. DOI:
https://doi.org/10.1175/MWR3305.1

SALIO, P. V.; NICOLINI, M.; SAULO, C.. Chaco low-level jet events characterization during the austral summer season.Journal of Geophysical Research, v.107, p.4816, 2002. DOI: http://doi.org/10.1029/2001JD001315

SANDERS, F.. Upper-Level Geostrophic Diffluence and Deepening of Surface Lows. Weather and Forecasting. v.8, p.339-344, 1993.

SELUCHI, M. E.; SAULO, A. C.. Baixa do Noroeste Argentino e Baixa do Chaco: Características, diferenças e semelhanças. Revista Brasileira de Meteorologia, v.27, n.1, p.49-60, 2012. DOI: http://dx.doi.org/10.1590/S0102-77862012000100006

SORTAIS, J. L.; CAMMAS, J. P.; YU, X. D.; RICHARD, E.; ROSSET, R.. A Case Study of Coupling between Low-and Upper-Level Jet-Front Systems: Investigation of Dynamical and Diabatic Processes. Monthly Weather Review, v.121, n.8, p.2239-2253, 1993. DOI: https://doi.org/10.1175/15200493(1993)121<2239:ACSOCB>2.0.CO;2

TEIXEIRA, M. S.; SATYAMURTY, P.. Dynamic and Synoptic Characteristics of Heavy Rainfall Episodes in Southern Brazil. Monthly Weather Review, v.115, p.598-617, 2007. DOI: https://doi.org/10.1175/MWR3302.1

UCCELINI, L. W.; JOHNSON, D. R.. The Coupling of Upper and Lower Tropospheric Jet Streaks and Implications for the Development of Severe Convective System, Monthly Weather Review, v.107, p.682-703, 1979. DOI: https://doi.org/10.1175/15200493(1979)107<0682:TCOUAL>2.0.CO;2

WALLACE, J. M.; HOBBS, P. V.. Atmospheric Science: An Introductory Survey. 2 ed. San Diego: Elsevier, 2006.

A CBPC - Companhia Brasileira de Produção Científica (CNPJ: 11.221.422/0001-03) detém os direitos materiais desta publicação. Os direitos referem-se à publicação do trabalho em qualquer parte do mundo, incluindo os direitos às renovações, expansões e disseminações da contribuição, bem como outros direitos subsidiários. Todos os trabalhos publicados eletronicamente poderão posteriormente ser publicados em coletâneas impressas sob coordenação da Sustenere Publishing, da Companhia Brasileira de Produção Científica e seus parceiros autorizados. Os (as) autores (as) preservam os direitos autorais, mas não têm permissão para a publicação da contribuição em outro meio, impresso ou digital, em português ou em tradução. 